\title{
Corporate Governance, Financial Constraint, and Value of Cash Holdings: Research from the Perspective of Ultimate Controllers
}

\author{
Weibin Zhao \\ Guodian Finance Corporation Limited, Beijing, China \\ Email: zhaoweibin@sina.cn
}

How to cite this paper: Zhao, W.B. (2016) Corporate Governance, Financial Constraint, and Value of Cash Holdings: Research from the Perspective of Ultimate Controllers. Modern Economy, 7, 1096-1119. http://dx.doi.org/10.4236/me.2016.710111

Received: April 29, 2016

Accepted: September 11, 2016

Published: September 14, 2016

Copyright $\odot 2016$ by author and Scientific Research Publishing Inc. This work is licensed under the Creative Commons Attribution International License (CC BY 4.0).

http://creativecommons.org/licenses/by/4.0/ (c) (i) Open Access

\begin{abstract}
This paper takes into consideration the character of China as an emerging market and distinguishes between the ultimate-controller trait of the central government and the local government. This paper conducts the analysis using the corporate governance and financial character perspectives, based on agency theory and financial constraint theory. The findings show that corporate governance is the main reason for values of cash holdings of SOEs are lower than those of private firms. Moreover, values of cash holdings of SOEs controlled by the central government are higher than those of cash holdings of firms controlled by local governments. The difference could be attributed to the observation that central government-controlled SOEs have better governance and investment opportunities compared with the local governmentcontrolled ones. The objectives of this paper are to determine the factors influencing the difference between cash holdings of state-owned enterprises (SOEs) and private firms, and to analyze the influence of governments at different levels on value of cash holdings of SOEs in China. Results of the analysis are expected to aid in understanding of how corporate governance and financial constraint affect value of cash holdings of firms.
\end{abstract}

\section{Keywords}

Ultimate Controller, Government Control, Value of Cash Holdings, Corporate Governance, Financial Constraint

\section{Introduction}

How to determine the value of liquidity is one of the 10 unsolved problems in finance [1]. Motivations for holding cash vary across companies. Some firms hold cash to meet 
operating needs or seize profitable investment opportunities as they arise. In this case, cash gives the firm flexibility and is regarded as a particularly valuable resource during times of financial constraint. In other firms, some insiders who have management control exploit corporate resources to generate personal benefits. Although many kinds of assets can be turned into private benefits, cash reserves are especially at risk of being turned into private benefits [2]. As Jensen points out, when managers have more cash flow at their disposal, they are inclined to overinvest in projects with negative net present values (NPVs) to pursue their own interest at the expense of the interest of shareholders [3], thereby discounting the value of cash holdings. In light of this analysis, hoarding cash instead of distributing cash as dividends may decrease firm value. This observation suggests that decision on what to do with cash holdings is an important factor affecting firm value.

Research recently has paid attention to the influence of institutional background on corporate finance [4]. Studies on the topic reveal that institutional factors, such as government control and property rights, play an important role in financial policy. Government control refers to the presence of government ownership of a firm. Except for property rights, influence of official hierarchy could not be ignored. Strong local governments are found in many parts of the world (e.g., China, India, Russia, Brazil, Argentina etc), where more than half of the global population lives [5]. In spite of this widespread anecdotal evidence, the distinction between central and local governments has received little attention in the academic literature.

Existing literature related to the research of cash holdings concentrates on two fields, namely, the determinants of cash holdings and the value of cash holdings, the latter means the value that investors assign to the cash held by a firm. As far as the value of cash holdings is concerned, studies find that firm-level financial characters and corporate governance are two key influential factors. Literature from recent years focuses on country-level corporate governance analyses [6]. For example, studies on Chinese institution system take into consideration the plural property rights system in China, and classify firms as private and state-owned ones [7]-[9]. However, existing research on value of cash holdings does not explore the influence of government on governance and financial character of firms, and does not consider property ownership. In the light of the ultimate-controller character, SOEs are firms controlled by the government. However, there may be a difference between the incentives granted to SOEs by the central and local governments, and between the behaviors of the central and local governments as far as governing SOEs is concerned [10].

Various institutional factors fundamentally influence business organizations and managerial behaviors in emerging markets. These factors include government quality and state ownership, among others [11]. China serves as a good example to understand the different factors influencing financial characteristics of firms, to distinguish between corporate governance in private firms and in SOEs, and to determine the difference between central and local governments in terms of governance of SOEs. In China, firms are classified either as SOEs or private enterprises. Private firms are market-oriented 
businesses that have no direct relation with government, while SOEs are controlled by governments. Heavy government intervention in business activities is common in China. Based on the current administrative system for SOEs in China, SOEs are controlled by different levels of governments. Government system is a complex interest group wherein the central government acts as the highest principal and the local governments operate as agents of the central government. Their control of SOEs is not similar [12]. This present study concentrates on the Chinese special institutional background, classifies SOEs according to government ultimate-controller level, and analyzes the difference between values of cash holdings of SOEs controlled by the central government and SOEs controlled by local governments in China. Unlike previous studies, this present study does not regard SOEs as being uniform enterprises. Through the comparison of values of cash holdings of private firms and SOEs controlled by the central government and local governments, this study provides a comprehensive view on cash holdings in an emerging market.

This paper provides two contributions to existing literature. First, this paper takes into consideration the emerging-market characteristic of China, provides evidence that corporate governance affects value of cash holdings of firms, and shows that financial constraint has very minimal influence on value of cash holdings for SOEs compared with private firms. Second, this paper takes into account of the influence of governments at different levels, which has been ignored so far in existing literature, and finds that values of cash holdings of central government-controlled SOEs are higher than those of local government-controlled SOEs. The difference between cash holdings of central government-controlled and local government-controlled SOEs may be attributed to their manner of control, governance, and the difference in financial characteristics of the two types of SOEs.

The remainder of this paper is organized as follows. Section 2 briefly reviews the theoretical literature on value of cash holdings. The literatures can be classified into two perspectives, namely, financial character and corporate governance. Section 3 presents the institutional background and the hypotheses. Section 4 describes the research design. Section 5 explains the empirical findings and analysis. Section 6 discusses results of robust tests. Section 7 provides the conclusion of the study.

\section{Literature Review}

In a perfect capital market, there are no transaction costs and agency costs. Corporations can finance projects with positive NPV by tapping the financial market. Meanwhile, managers do not pursue personal interest at the expense of shareholders' interest. In this case, the decision to whether or not distribute cash as dividends does not influence value of firms. This means the book value of cash equals the market value of cash. However, if the capital market is not perfect, transaction costs and agency costs could result in discounted cash holdings, thereby affecting value of cash holdings for shareholders. Two perspectives are identified for the analysis of valuation for cash holdings. 


\subsection{Corporate Governance Perspective}

Studies on corporate governance are concerned mainly on whether executives use cash to pursue personal benefit. Dittmar and Mahrt-Smith find that good corporate governance has a positive effect on the value of excess cash and on the marginal value of total cash [13]. For firms that have extensive anti-takeover provisions and a low level of large shareholder monitoring, which are thought of indicators of poor governance, the market value of excess cash is found to be approximately one-half of the value of excess cash for firms that are well governed. Depending on the measure of corporate governance, the marginal value of $\$ 1.00$ held by poorly governed firms varies from $\$ 0.42$ to $\$ 0.88$, compared with $\$ 1.27$ to $\$ 1.62$ for well governed firms. Dittmar and Mahrt-Smith further show that firms with poor corporate governance dissipate cash more quickly and suffer from lower operating performance [13]. Tong finds that firm diversification reduces the value of cash in both financially unconstrained and constrained firms [14]. Firm diversification has a negative impact on the value of cash among firms with a lower level of corporate governance. It shows that firm diversification reduces the value of cash holdings resulting from agency problems. Yuan et al. find firm diversification to have no significant impact on value of cash holdings, which they say depend on the power of block-holder [15]. If a block-holder owns a large share, it can properly monitor the executives, and restrict them from moving against the interest of shareholders, and improve cash holdings of the firm. Kusnadi finds that the incremental value of holding excess cash is negative for firms with poor governance (such as those with a single-leadership structure, large board size, and small representation of independent directors in the audit committee) [16]. The discounts associated with these firms reflect recognition by minority shareholders of the possibility of managerial entrenchment. Huang and Zhang find that cash holdings are rewarded with higher market valuation when greater disclosure improves transparency of a firm [5]. It suggests that enhanced transparency, which is achieved through greater disclosure, improves external monitoring and thus limits ability of insiders to accumulate cash to expropriate minority shareholders. Fresard and Salva find that investors systematically place a valuation premium on the excess cash of foreign firms that cross-list on US exchanges or overthe-counter compared with that of their domestic peers [17]. Moreover, the excess cash premium turns out to be magnified for firms located in countries where shareholder protection is weak. The reason for this is that stricter legal rules, greater transparency, and increased monitoring that accompany a US cross-listing corporation help mitigate risk of diversion of cash for personal benefits.

Because controlling shareholders extract more private benefits from a firm they control if investor protection is weak, block-shareholder may use cash to tunnel and investors may discount the value of cash reserves. Pinkowitz et al. find that the relation between cash holdings and firm value is much weaker in countries with poor investor protection than in other countries [18]. Luo and Qin find that strong investor protection could restrict tunneling, thereby allowing investors to give value premium for cash holdings [19]. Li finds that controlling shareholders of family-owned companies that go 
public through restructuring of existing listed companies prefers to tunnel [20]. Common investors should be able to predict that and thus discount the value of cash.

In China, there are studies on the influence of property rights. Shen et al. find that the market value of 1 yuan worth of cash holdings is about 0.769 yuan when control rights of a corporation disparate cash-flow rights and when the ultimate controlling shareholder is the state [7]. The value is about 1.206 yuan when the proportion of control rights to cash flow rights is at least 1 but the ultimate controlling shareholders are non-state shareholders. The finding shows that the higher preference for large cash holdings of state ultimate-controlling shareholders is a motive for expropriation under the context of the separation of control rights from cash flow rights. The result is consistent with "grabbing hand" hypothesis advanced by Shleifer and Vishny. Yang and Zhang find that in China the market value of cash holdings is less than the book value, and state ownership reduces the market value of cash holdings [9]. Gu and Sun find that the value of additional cash held by non-SOEs is higher because agency problems in private enterprises are less severe than those in SOEs [8].

\subsection{Financial Constraint Perspective}

Financial constraints hinder companies from securing funds from the financial market to implement projects. Faulkender and Wang find that the marginal value of cash declines with larger cash holdings, higher leverage, better access to capital markets, and as firms choose greater cash distribution via dividends rather than repurchases. The marginal value of cash for the mean-constrained firms is higher than the mean-unconstrained firms [21]. This finding suggests that the market perceives the presence of market frictions that raising outside capital costly. In this case, the market rewards firms that retain liquidity with higher valuations, thereby making said firms create more value compared with those having less internal cash. Denis and Sibilkov find that the association between investment and cash holdings value is stronger for financially constrained firms than for unconstrained firms [22]. The finding implies that higher cash holdings allow constrained firms to undertake value-increasing projects that might otherwise be bypassed.

\subsection{Corporate Governance, Financial Constraint, and Government Control}

State ownership is typically associated with low productivity. As Shleifer points out, poor performance of SOEs is not only due to the lack of ownership incentives but to the tendency of bureaucrats and politicians to interfere by diverting wealth of SOEs. Bureaucrats may use their position to interfere in the operations of SOEs, particularly in a manner that will make the firms support the economy [11]. Interference may be in the forms of taxation, regulation, state ownership, and government's influence and control of various aspects of business, namely, output, production process, and inputs like labor, land, mines, energy, infrastructures, and financing. Government interference is absent in private firms, and the government does not support operations of private 
firms. For example, four of the biggest state-owned banks in China are reluctant to lend to the private sector but easily extend funds to SOEs in the name of public interest [23].

There are two views on government influence on firms, namely, helping hand hypothesis and grabbing hand hypothesis. This present paper emphasizes the difference between the two hypotheses as far as the central government and local governments are concerned. Since the implementation of the fiscal system and the political-promoting mechanism, local governments have had more incentives to expropriate controlled firms. Zou et al. find that local government-controlled firms experience a more negative market reaction to the announcement of purchase of directors' liability insurance than central government-controlled firms do [24]. Chen et al. find that central governmentcontrolled firms trade at higher Tobin's $\mathrm{Q}$ compared with local government-controlled firms [25]. These findings suggest that difference in the kind of government control results in difference in performance of SOEs. Other studies take into account Chinese special institutional background and recognize the difference between cash holdings of SOEs and private enterprises and get difference results from corporate governance and financial characteristics between the two kinds of firms. A fact that cannot be neglected is that SOEs have been administrated and controlled by governments of different levels according to the new state-owned asset administrative system that took effect in 2002. Studies that regard SOEs as uniform neglect the influence of the difference in ultimate controller. China is an emerging and transitional economy where the government plays an important role. Taking into consideration the levels of government may help enrich the understanding of cash holdings under the Chinese institution background.

\section{Institution Background and Hypotheses Development}

\subsection{Institution Background Analysis}

The Constitution of the People's Republic of China states as a national and basic rule that the public sector takes a leading position in the economy and develops diverse forms of ownership of properties during the primary stage of socialism. As a socialist country, China must keep public ownership as the foundation of its socialist economic system. However, China has taken a reform-and-opening policy since 1978. Since then, private firms have rapidly grown and have played a very important role in the economy. On the contrary, SOEs have slowly grown. In 2002, the 16th CPC nation congress report was released. It put forward the initiative of both the central government and the local governments to uphold state ownership and to establish a state-property management system, under which the two levels of governments perform the responsibilities of investors on behalf of the state. As such, the governments enjoy owners' equity and rights, assume owners' obligations and duties, and administer assets, personnel, and other affairs. The central government and the provincial and municipal (prefectural) governments should set up state property management organizations. In 2003, State-owned Assets Supervision and Administration Committee of the State Council (SASAC) started to operate. According to the regulation on state-asset administration issued by State Council in May 2003, the central government acts as the agent of the 
state in performing the functions as investor in large SOEs, infrastructure, and important natural resources that have a vital bearing on the lifeline of the national economy and state security, while local governments represent the state in performing the functions of investors with regard to other state property. However, the new phenomenon of "guojinmintui", i.e., the rise of state ownership and the decline of private firms, recently has emerged in China. The entry barriers for non-SOEs have increased in recent years and have adversely affected the economy. This phenomenon is in sharp contrast with the long trend of China's reform and open policy that had been in effect since 1978.

China built on its strong local governments at various levels by allowing them to compete in attracting investments, developing infrastructure, and improving the local business environment. Decentralization policies, including fiscal reforms in 1994, gave sub-national governments the incentives and the resources to aggressively pursue local development objectives [26]. The 1994 fiscal reform resulted in harder budget constraints to local governments. The fiscal reform carried out the tax-sharing scheme between the central government and local governments to improve the fiscal power of the former. Unlike in other countries where taxes are collected by the central government and then allocated to sub-national governments, local authorities in China collect all tax revenues and remit portions to higher levels of government. The amount remitted to the central government depends on provincial receipts and the tax-sharing formula between the central government and the provincial governments. Before the 1994 fiscal reform, the share in fiscal revenues of local governments was over 70 percent. After the reform, their share had fallen, reaching only 44.8 percent in 1994. Since then, the share has never exceeded 50 percent. On the contrary, the 1994 fiscal reform did not change the shares of the central government and local governments in public expenditures. This means local governments have carried heavier burden since the fiscal reform. The desire to ease the added burden has motivated local governments to intervene in the operations of SOEs, such as through the implementation of social and economic projects.

Under the law, local governments must unconditionally comply with rules stated under the Beijing Administration. In reality, however, they are more often controlled by local party officials, and local governments work to serve their own interests. Local governments exert significant effort on tax collection and running SOEs to earn revenues. The central government does not have to do the same given the increase in its financial power since 1994. Ways of controlling SOEs by governments at different levels vary, thereby resulting in difference in corporate governance and financial characteristics of SOEs. The difference influences how investors how to value cash holdings of the firms.

\subsection{State Owned and Value of Cash Holdings}

Agency problems between shareholders and debt holders could affect value of cash holdings. Jensen develops the free-cash flow argument that states that managers hold excess cash and enjoys flexibility to spend it in pursuit of their own interests [3]. When 
managers fund projects using cash holdings, they do not observe the discipline of raising funds by tapping the capital markets. Moreover, they are able to undertake projects that capital markets normally would not finance. Good corporate governance should limit conflict between shareholders and managers. Compared with private firms, SOEs have closer relation with governments. Because the government is the ultimate controller, government monitoring is important for managers in SOEs. With inefficient interna1 and external governance mechanisms, the systems of constraint, supervision, and incentive cannot effectively reduce the agency costs, thus making the principal-agent problem more serious among SOEs than among private firms. In private enterprises, shareholders have the right of contractual control and residual claim, which encourage them either to be directly involved in operations or to more actively oversee managers. Internal supervision can make up for the lack of effective market supervision, thereby reducing agency costs. Contrary to experience in private firms, agency problems and moral hazards become prevalent, and the marginal value of the cash is reduced, in SOEs when they hold large amounts of cash.

Value of cash holdings for financially constrained companies is higher than that for unconstrained firms [21]. However, in an emerging market like China, market opportunities abound and strong companies prefer to exercise superiority. Pinkowitz and Williamson find that growth opportunity is an important factor to determine the value of cash holdings given that future development affects the future value of cash holdings

[6]. In an economy full of opportunities, financially constrained companies that hold significant amounts of cash send a message to the market that it had not find good investment projects. Said message may undermine shareholders value in the future. The influence on value of cash holdings of SOEs and private firms is complex. On one hand, SOEs may obtain government support, mostly in terms of financial resources. Examples of such support are IPO quota and bank loans, which help SOEs finance projects by easily tapping the capital market and without enduring financial constraint. Under such conditions, hoarding of cash could bring negative effects on SOEs. On the other hand, the rise of state ownership combined with the deterioration of the private sector recently has become a trend in China. Reserved cash of SOEs may enhance their ability to acquire properties and to expand their businesses, thereby strengthening their market position in the future. In contrast, private firms may hoard cash to invest in new and superior business initiatives in the future, but the increased barriers to market entry could hinder their efforts.

The first hypothesis, therefore, is as follows: The value of cash holdings of SOEs is lower than that of private firms. Agency problem negatively affects value of cash holdings, and the negative correlation is stronger among SOEs. Holding of cash by financially constrained firms may decrease the value of cash holdings both for SOEs and private firms.

\subsection{Corporate Governance and Value of Cash Holdings}

For SOEs, agency problem between shareholders and managers prevail. However, accompanied with the fiscal system decentralization and SOE reform, interventions by 
the central and local governments have been in different forms, resulting in different effects to the agency problem. Central government-controlled enterprises are now more strictly monitored by the government and the CPC [27]. They are now audited by the state auditing administration, and managers may be in the face of more constraints on opportunistic behavior. Because executives and top managers of central SOEs are important part of CPC (their nomination should obtain agreement of Personal Commissions of $\mathrm{CPC}$ ), they also are overseen by Central Commissions for the Disciplinary Inspection of the CPC. Because SOEs controlled by the central government play a very important role in the economy, the government must require these firms to strictly implement laws, regulations, and policies so that they would serve as models. Moreover, managers in SOEs controlled by the central government have close connection with top government officials and have more chances of becoming high-rank government officials as well [28]. If they The Constitution of the People's Republic of China states as a national and basic rule that the public sector takes a leading position in the economy and develops diverse forms of ownership of properties during the primary stage of socialism. Complying with the government policies, they get better chances of promotion. In summary, over-investment and other irrational investment activities by executives could be reduced and non-productive perk consumption could be restricted in central government-controlled enterprises. When these enterprises hold large amounts of cash, higher authorities pay more attention to their liquid assets. Therefore, managers are less likely to seek private benefits because agency costs are under control to some extent.

Under the current political system in China, local government officials who want to be promoted must make their jurisdictions enjoy more significant economy growth compared with the other regions [29]. The local government that manages a regional economy mainly takes into consideration local economic development rather than national economic development. In this sense, SOEs controlled by local governments have become bargaining chips by which the local governments try to achieve governments' political goals. It also means local governments rely on support from SOEs controlled by local governments. SOEs controlled by the local governments may be under loose supervision [27]. As the ultimate controller, a local government is more likely to tolerate opportunistic behaviors of local SOEs. The consequence is that local SOEs lack an effective incentive and restraint mechanism. In contrast to SOEs controlled by the central government, SOEs controlled by local governments hold large amounts of cash and their managers have more chances of seeking private benefits through over-investment [28]. Because of the increase in irrational and non-productive investment opportunities taken by managers, the value of cash holdings diminishes.

In line with the above mentioned analysis, this paper puts forward the second hypothesis 2: The value of cash holdings of firms controlled by the central government is higher than that of firms controlled by local governments; agency cost could reduce value of cash holdings, but the negative correlation between agency cost and value of cash holdings is weaker for firms controlled by the central government. 


\subsection{Financial Constraint and Value of Cash Holdings}

Hoarding cash may avoid underinvestment if firms face financial constraint. In China, 90 percent of financing came from commercial banks [30]. Given the fiscal burden that came with the implementation of the fiscal reform, local governments cannot finance SOEs by fiscal resource, and thus have become more motivated to intervene in government-run banks by making them lend to SOEs. The banking system in China has long been functioning as a mechanism for using savings to meet public policy goals. In general, SOEs are able to easily obtain bank loans partly because most commercial banks also are owned by the state.

If government-controlled companies face financing constraint, a possible reason for this is lack of good prospects. Since the implementation of the banking system reform in the 1990s, commercial banks have emphasized safety of returns and loans, especially after strategy investors from overseas have joined them. Based on this perspective, financial constraint for SOEs that had implicit connections with banks in China could be regarded as a negative signal. Therefore, holding of cash by financially constrained SOEs may be negatively correlated with the value of cash holdings.

According to the new state-owned enterprises administration system in China, local government-controlled firms are generally smaller than central government-controlled firms. Moreover, SOEs controlled by the central government operate nationwide, while most SOEs controlled by local governments do business in local regions. As a consequence, SOEs controlled by the central government have developed into big groups of companies, diminishing their reliance on bank financing. On the contrary, bank financing is the main funding source for most local government-controlled SOEs. The observations suggest that the negative correlation between financing constraint and value of cash holdings is weaker for central government-controlled SOEs than for local government-controlled SOEs. The third hypothesis is as follows: As far as SOEs are concerned, holding of cash by financially constrained firms could decrease the value of their cash holdings; this correlation is weaker for firms controlled by the central government than for firms controlled by local governments.

\section{Research Design}

\subsection{Data and Samples}

This paper selects all normally traded A-share companies listed on the Shanghai Stock Exchange and Shenzhen Stock Exchange between 2002 and 2009. The study excludes listed companies in the financial sector. Because the study needs to calculate the changes in cash holdings, net assets earnings, interests, dividends, and capital expenditures for different years, the actual calculation range is from 2003 to 2008. To be included in sample, a company must have been listed for at least one year. The study winsorised major variables at the 1 percent and 99 percent levels. After the elimination process, 7457 sample observations are obtained. Table 1 shows the whole sample and subsample observation numbers in different years. Private companies are those whose ultimate controllers are private entities, foreign institutions, or organizations that have 
Table 1. Sample observations distribution.

\begin{tabular}{cccccccc}
\hline Year & 2003 & 2004 & 2005 & 2006 & 2007 & 2008 & Total \\
\hline All Sample & 1092 & 1186 & 1209 & 1249 & 1327 & 1394 & 7457 \\
Private Companies & 269 & 340 & 356 & 417 & 496 & 535 & 2413 \\
$\begin{array}{c}\text { Local Governments } \\
\text { Controlled Companies }\end{array}$ & 623 & 640 & 625 & 590 & 576 & 581 & 3635 \\
$\begin{array}{c}\text { Central Government } \\
\text { Controlled Companies }\end{array}$ & 200 & 206 & 228 & 242 & 255 & 278 & 1409 \\
\hline
\end{tabular}

no direct relation with governments. Listed companies controlled by the central government are defined as those whose ultimate controller is the SASAC of the State Council or other Ministries on attachment to the State Council of P.R.C. Listed companies controlled by local governments refer to firms whose ultimate controllers are province, city, county, or district governments. In this paper, all financial data are sourced from the CSMAR and Wind financial databases. The analysis software used is STATA 10.

\subsection{Model and Variables Definition}

In this paper, the studies of Fama and French [31], Pinkowitz and Williamson [6], and Dittmar and Mahrt-Smith [13] are used as references. According to the hypotheses development, this paper uses two following basic regression models.

Model 1:

$$
\begin{aligned}
& \mathrm{mv}_{\mathrm{i}, \mathrm{t}}=\beta_{0}+\beta_{1} \mathrm{cash}_{\mathrm{i}, \mathrm{t}}+\beta_{2} \mathrm{type}_{\mathrm{i}, \mathrm{t}}+\beta_{3} \mathrm{type}_{\mathrm{i}, \mathrm{t}} * \operatorname{cash}_{\mathrm{i}, \mathrm{t}}+\beta_{4} \mathrm{earn}_{\mathrm{i}, \mathrm{t}}+\beta_{5} \text { dearn }_{\mathrm{i}, \mathrm{t}} \\
& +\beta_{6} \text { dearn }_{\mathrm{i}, \mathrm{t}+1}+\beta_{7} \text { dna }_{\mathrm{i}, \mathrm{t}}+\beta_{8} \mathrm{dna}_{\mathrm{i}, \mathrm{t}+1}+\beta_{9} \text { inter }_{\mathrm{i}, \mathrm{t}}+\beta_{10} \text { dinter }_{\mathrm{i}, \mathrm{t}}+\beta_{11} \text { dinter }_{\mathrm{i}, \mathrm{t}+1} \\
& +\beta_{12} \operatorname{divid}_{\mathrm{i}, \mathrm{t}}+\beta_{13} \operatorname{ddivid}_{\mathrm{i}, \mathrm{t}}+\beta_{14} \text { ddivid }_{\mathrm{i}, \mathrm{t}+1}+\beta_{15} \operatorname{capex}_{\mathrm{i}, \mathrm{t}}+\beta_{16} \text { dcapex }_{\mathrm{i}, \mathrm{t}} \\
& +\beta_{17} \text { dcapex }_{\mathrm{i}, \mathrm{t}+1}+\beta_{18} \mathrm{dmv}_{\mathrm{i}, \mathrm{t}+\mathrm{1}}+\sum \beta_{19+\mathrm{i}} \text { ind }+\sum \beta_{39+\mathrm{j}} \text { year }+\varepsilon_{\mathrm{i}, \mathrm{t}}
\end{aligned}
$$

Model 2:

$$
\begin{aligned}
& \operatorname{mv}_{\mathrm{i}, \mathrm{t}}=\beta_{0}+\beta_{1} \operatorname{cash}_{\mathrm{i}, \mathrm{t}}+\beta_{2} \text { EXPLAIN }_{\mathrm{i}, \mathrm{t}}+\beta_{3} \text { type }+\beta_{4} \text { EXPLAIN }_{\mathrm{i}, \mathrm{t}} * \operatorname{cash}_{\mathrm{i}, \mathrm{t}} \\
& +\beta_{5} \text { type }^{*} \text { cash }+\beta_{6} \text { EXPLAIN }_{\mathrm{i}, \mathrm{t}} * \text { type }+\beta_{7} \text { type }^{*} \text { EXPLAIN }^{*} \text { cash }_{\mathrm{i}, \mathrm{t}} \\
& +\beta_{8} \text { earn }_{\mathrm{i}, \mathrm{t}}+\beta_{9} \text { dearn }_{\mathrm{i}, \mathrm{t}}+\beta_{10} \text { dearn }_{\mathrm{i}, \mathrm{t}+1}+\beta_{11} \text { dna }_{\mathrm{i}, \mathrm{t}}+\beta_{12} \text { dna }_{\mathrm{i}, \mathrm{t}+1}+\beta_{13} \text { inter }_{\mathrm{i}, \mathrm{t}} \\
& +\beta_{14} \operatorname{dinter}_{\mathrm{i}, \mathrm{t}}+\beta_{15} \operatorname{dinter}_{\mathrm{i}, \mathrm{t}+1}+\beta_{16} \operatorname{divid}_{\mathrm{i}, \mathrm{t}}+\beta_{17} \mathrm{ddivid}_{\mathrm{i}, \mathrm{t}}+\beta_{18} \mathrm{ddivid}_{\mathrm{i}, \mathrm{t}+1}+\beta_{19} \text { capex }_{\mathrm{i}, \mathrm{t}} \\
& +\beta_{20} \text { dcapex }_{\mathrm{i}, \mathrm{t}}+\beta_{21} \text { dcapex }_{\mathrm{i}, \mathrm{t}+1}+\beta_{22} \mathrm{dmv}_{\mathrm{i}, \mathrm{t}+1}+\sum \beta_{23+\mathrm{i}} \mathrm{ind}+\sum \beta_{43+\mathrm{j}} \text { year }+\varepsilon_{\mathrm{i}, \mathrm{t}}
\end{aligned}
$$

This paper uses KZ index and WW index as the indicator of financial constraint [32] [33]. This paper calculates the WW index for sample firms each year according to the following equation: $\begin{aligned} \text { WWindex }_{\text {it }}= & -0.091 \text { cashflow }_{\text {it }}-0.062 \text { divdum }_{\text {it }}+0.021 \text { tltd }_{\text {it }} \\ & -0.044 \text { size }_{\text {it }}+0.102 \text { indgrowth }_{\text {It }}-0.035 \text { growth }_{\text {it }} .\end{aligned}$

In the equation, cashflow ${ }_{\mathrm{it}}$ is net profit plus depreciation divided by the total assets for firm $i$ in year $t$, divdum $_{\mathrm{it}}$ is a dummy variable that equals 1 if firm i pays out a cash dividend in year $t$ and zero otherwise, $\operatorname{ltd}_{\mathrm{it}}$ is the ratio of long-term debt to the book value of total assets, indgrowth ${ }_{\mathrm{It}}$ is an indicator that the firm belongs to industry sales 
growth, and growth ${ }_{\mathrm{it}}$ is the firm's sales growth in year t. Observations whose WW indexes are no less than the median value of WW index are seen as financially constrained firms. This paper uses the works of Kaplan and Zingles [32], and Liang et al. [34] as references. In the latter, the $\mathrm{KZ}$ index for Chinese listed companies is calculated using the following formula:

$$
\begin{aligned}
\text { KZindex }_{\mathrm{it}}= & -8.971 \mathrm{cash}_{\mathrm{it}} / \mathrm{asset}_{\mathrm{it}}-13.874 \text { cashflow }_{\mathrm{it}} / \text { asset }_{\mathrm{it}} \\
& -3.712 \text { cashdivid }_{\mathrm{it}} / \text { asset }_{\mathrm{it}}+5.601 \text { lever }_{\mathrm{it}}+0.828 \text { growth }_{\mathrm{it}} .
\end{aligned}
$$

In the equation, cash $_{\mathrm{it}}$ is cash holdings for firm $\mathrm{i}$ at the end of year $\mathrm{t}$, asset $\mathrm{it}_{\mathrm{it}}$ is total asset for firm $i$ at the end of year $t$, cashflow $_{i t}$ is net profit plus depreciation for firm $i$ in year $t$, cashdivid ${ }_{i t}$ is cash dividend for firm $i$ in year $t$, lever $_{i t}$ is debt divided by the total assets for firm $i$ at the end of year $t$, and growth ${ }_{i t}$ is the sales growth of firm $i$ sales in year $\mathrm{t}$. In each fiscal year, firms are ranked according to the $\mathrm{KZ}$ index. Firms with $\mathrm{KZ}$ indexes of no less than the median value of $\mathrm{KZ}$ index are regarded as financially constrained firms.

Table 2 shows the definition of variables. In the two models, type indicates state and central variables. To control for heteroscedasticity, all control variables (excluding industry and year) are divided by the total asset. According to hypotheses 1 and 2, the regression coefficient of state ${ }^{*}$ cash should be negative while central ${ }^{*}$ cash should be positive in model 1 . In model 2 , the regression coefficient of agency*ash should be negative. Taking into consideration the different types of ultimate controllers, the regression coefficient of the state ${ }^{*}$ agency ${ }^{*}$ cash should be negative, while central ${ }^{\star}$ agency ${ }^{*}$ cash should be positive. This means control of the central government may weaken the passive influence of the agency problem on value of cash holdings.

As for financial characters, $\mathrm{fc}$ variable is an indication of financial constraint. If the hypothesis 1 and hypothesis 3 are right, the regression coefficient of $\mathrm{fc}^{*} \mathrm{cash}$ should be negative. Furthermore, the coefficient of state ${ }^{\star} f c^{\star} c a s h$ should be insignificant. This means that unlike in private firms, holding of cash by financially constrained SOEs should be not systematically related to market value. The regression coefficient of central ${ }^{\star} \mathrm{fc}^{*}$ cash should be positive. It implies that reservation of cash by financially constrained SOEs could bring negative effects on firm value, but this relation may be weaker for SOEs controlled by central government than for SOEs controlled by the local government. Table 3 shows the abovementioned prediction.

\section{Empirical Analysis}

\subsection{Descriptive Statistics of the Main Variables}

Descriptive statistics of the variables used to predict the value of cash holdings are shown in Panel A of Table 4. The mean numbers of cash holdings for SOEs and private sectors are 0.159 and 0.182 , respectively. The numbers for central government-controlled SOEs and local government-controlled SOEs are 0.176 and 0.151 , respectively. In Panel B and Panel C of Table 4, the difference in the main variables between the two types of sub-sample is analyzed through the conduct of mean and median tests. Results 
Table 2. Variables definition.

\begin{tabular}{|c|c|c|}
\hline \multicolumn{2}{|c|}{ Variable } & Definition \\
\hline \multirow[t]{3}{*}{$\begin{array}{l}\text { Explained } \\
\text { Variable }\end{array}$} & $\mathrm{mv}$ & $\begin{array}{c}\text { Firm value } \\
\mathrm{MV}=(\text { market value of equity }+ \text { book value of debt }) / \text { book value of assets }\end{array}$ \\
\hline & cash & $\begin{array}{c}\text { Cash holdings, } \\
\text { Cash }=(\text { cash and short-term investment or tradable securities }) / \text { total assets }\end{array}$ \\
\hline & state & $\begin{array}{l}\text { Dummy variable, if the ultimate controller is } \\
\text { government, it equals } 1 \text {, otherwise is } 0 .\end{array}$ \\
\hline \multirow[t]{6}{*}{$\begin{array}{l}\text { Explanatory } \\
\text { Variables }\end{array}$} & central & $\begin{array}{l}\text { Dummy variable, if the ultimate controller } \\
\text { is central government, it equals } 1 \text {, otherwise is } 0 \text {. }\end{array}$ \\
\hline & agency & Agent cost, agency $=$ administrative expenses $/$ total assets \\
\hline & $\mathrm{fc}$ & $\begin{array}{l}\text { Financial constraint index, fc equals } \\
\text { one if firms labeled financial constraint. }\end{array}$ \\
\hline & $\operatorname{earn}_{\mathrm{i}, \mathrm{t}}$ & The operation profit in year $\mathrm{t}$ \\
\hline & dearn $_{\mathrm{i}, \mathrm{t}}$ & The change of operation profit between year $t$ and year $t-1$. \\
\hline & dearn $_{\mathrm{i}, \mathrm{t}+1}$ & The change of operation profit between year $t+1$ and year $t$ \\
\hline \multirow{5}{*}{$\begin{array}{c}\text { Control } \\
\text { Variables }\end{array}$} & $\mathrm{dna}_{\mathrm{i}, \mathrm{t}}$ & $\begin{array}{l}\text { The change of net assets } \\
\text { (total assets minus cash holdings) between year } \mathrm{t} \text { and year } \mathrm{t}-1\end{array}$ \\
\hline & $\operatorname{dna}_{i, t+1}$ & The change of net assets between year $t+1$ and year $t$ \\
\hline & inter $_{\mathrm{i}, \mathrm{t}}$ & $\begin{array}{l}\text { Interest expenses in year } t \text { (since the data can't } \\
\text { available, this paper replaces it with financial expenses) }\end{array}$ \\
\hline & dinter $_{\mathrm{i}, \mathrm{t}}$ & The change of interest expenses between year $t$ and year $t-1$ \\
\hline & dinter $r_{i, t+1}$ & The change of interest expenses between year $t+1$ and year $t$ \\
\hline \multicolumn{2}{|c|}{ Variable } & Definition \\
\hline & $\operatorname{divid}_{\mathrm{i}, \mathrm{t}}$ & The cash dividend in year $\mathrm{t}$ \\
\hline & $\operatorname{ddivid}_{\mathrm{i}, \mathrm{t}}$ & The change of cash dividend between year $t$ and year $t-1$ \\
\hline & ddivid $_{\mathrm{i}, \mathrm{t}+1}$ & The change of cash dividend between year $t+1$ and year $t$ \\
\hline & capex $_{i, t}$ & $\begin{array}{l}\text { Capital expenditure in year } t \text {, it equals cash paid to acquire fixed assets, } \\
\text { intangible assets and other long-term assets minus cash received from } \\
\text { disposal fixed assets ,intangible assets and other long-term assets in year } t \text {. }\end{array}$ \\
\hline & dcapex $_{\mathrm{i}, \mathrm{t}}$ & The change of capital expenditure between year $t$ and year $t-1$ \\
\hline & dcapex $_{\mathrm{i}, t+1}$ & The change of capital expenditure between year $t+1$ and year $t$ \\
\hline & $\mathrm{dmv}_{\mathrm{i}, \mathrm{t}+1}$ & The change of MV between year $t+1$ and year $t$ \\
\hline & ind & Industry dummy variables \\
\hline & year & Year dummy variables \\
\hline
\end{tabular}

suggest that differences in main variables between SOEs and private firms are significant. As for the difference between central government SOEs and local government SOEs, the T value and the $\mathrm{Z}$ value of $\mathrm{WW}$ index variable is not significant. 
Table 3. Expected sign of variables.

\begin{tabular}{|c|c|c|}
\hline Category & Variables & Expecting Sign \\
\hline \multirow{3}{*}{$\begin{array}{l}\text { Type of ultimate } \\
\text { controller }\end{array}$} & state $^{\star}$ cash & - \\
\hline & central $^{*}$ cash & + \\
\hline & agency $^{*}$ cash & - \\
\hline \multirow[t]{3}{*}{$\begin{array}{l}\text { Corporate } \\
\text { governance }\end{array}$} & state $^{\star}$ agency $^{*}$ cash & - \\
\hline & central $^{*}$ agency ${ }^{*}$ cash & + \\
\hline & $\mathrm{fc}^{*} \mathrm{cash}$ & - \\
\hline \multirow[t]{2}{*}{$\begin{array}{l}\text { Financial } \\
\text { constraint }\end{array}$} & state $^{\star} \mathrm{fc}^{\star}$ cash & $?$ \\
\hline & central ${ }^{\star} \mathrm{fc}^{\star} \mathrm{cash}$ & + \\
\hline
\end{tabular}

\subsection{Regression Test Result}

Table 5 shows the OLS regression result using model 1 and 2 for all samples. To save space, statistics of controlled variables are omitted (hereinafter the same). In column (1), regression coefficient of state* cash is -0.402 , which is significant at the $5 \%$ level, suggesting that market value of 1 yuan cash holdings for SOEs is 0.402 yuan lower than that of private firms. In column (2), coefficient of agency ${ }^{\star}$ cash is 13.066, which is significant at the $1 \%$ level and which contradicts expectation. One possible explanation for this result is that China is an emerging market where government quality is low compared with that in a developed country. Negative behaviors in an environment with low government quality are bribery and use of political connection by firms. The substantial values of firms in emerging markets come from the ability of owners to seek rent from government [35]. Administrative expenses are an important channel to connect with governments. Column (2) shows that agency is significantly positively correlated with mv, thereby proving the abovementioned observations. However, the coefficient of state $^{\star}$ agency ${ }^{*}$ cash is -18.138 and significant at the $1 \%$ level. This shows that unlike in private businesses, higher administrative expenses may mean higher conflict between shareholders and managers in SOEs, thereby making holding of cash reduce firm value. In column (3) and (4), $\mathrm{fc}^{\star}$ cash variable is significantly negatively correlated with $\mathrm{mv}$, but state $\mathrm{fc}^{\star} \mathrm{cash}$ is not. Therefore, compared with private firms, the value of cash holdings for SOEs is lower. The reason for this is that SOEs have more serious agency problems, and the value of their cash holdings is not significantly affected by financial constraint.

Column (1) in Table 6 shows that the coefficient of central ${ }^{*}$ cash is 0.502 , which is significant at the $5 \%$ level and which suggests that central-government control could improve the value of cash holdings. In column (2), coefficient of agency*ash is -12.768 , which is significant at the $1 \%$ level and which means that for firms that have more serious agency problems, holding of cash could decrease the value of cash holdings. The coefficient of central ${ }^{*}$ agency ${ }^{*}$ cash is 11.106 , which is significant at the $10 \%$ level and which suggests that central-government control could weaken the negative influence of agency cost on value of cash holdings. Moreover, it shows that the negative 
Table 4. Panel A: Descriptive statistics of main variables. Panel B: Mean test and median test for SOEs and private sectors. Panel C: Mean test and median test for central government controlled firms and local governments controlled firms.

Panel A

\begin{tabular}{|c|c|c|c|c|c|c|c|}
\hline \multicolumn{2}{|c|}{ Variable } & \multirow{2}{*}{$\begin{array}{c}\text { N of Obs } \\
7457\end{array}$} & \multirow{2}{*}{$\begin{array}{c}\text { Mean } \\
1.621\end{array}$} & \multirow{2}{*}{$\begin{array}{c}\text { Median } \\
1.146\end{array}$} & \multirow{2}{*}{$\begin{array}{c}\text { S.D } \\
1.328\end{array}$} & \multirow{2}{*}{$\begin{array}{c}\text { Min } \\
0.498\end{array}$} & \multirow{2}{*}{$\begin{array}{r}\text { Max } \\
10.978\end{array}$} \\
\hline & $\mathrm{mv}$ & & & & & & \\
\hline & cash & 7457 & 0.166 & 0.135 & 0.124 & 0.0002 & 0.866 \\
\hline All & state & 7457 & 0.679 & 1 & 0.467 & 0 & 1 \\
\hline \multirow[t]{5}{*}{ sample } & agency & 7457 & 0.048 & 0.041 & 0.035 & 0.004 & 0.257 \\
\hline & $\mathrm{fc}(\mathrm{KZ})$ & 7457 & 0.510 & 1 & 0.500 & 0 & 1 \\
\hline & $\mathrm{fc}(\mathrm{WW})$ & 7457 & 0.520 & 1 & 0.500 & 0 & 1 \\
\hline & $\mathrm{mv}$ & 5044 & 1.489 & 1.083 & 1.181 & 0.498 & 10.978 \\
\hline & cash & 5044 & 0.159 & 0.131 & 0.114 & 0.0007 & 0.805 \\
\hline SOEs & central & 5044 & 0.282 & 0 & 0.450 & 0 & 1 \\
\hline \multirow[t]{4}{*}{ sample } & agency & 5044 & 0.049 & 0.041 & 0.034 & 0.004 & 0.257 \\
\hline & $\mathrm{fc}(\mathrm{KZ})$ & 5044 & 0.516 & 1 & 0.499 & 0 & 1 \\
\hline & $\mathrm{fc}(\mathrm{WW})$ & 5044 & 0.516 & 1 & 0.499 & 0 & 1 \\
\hline & $\mathrm{mv}$ & 2413 & 1.910 & 1.354 & 1.556 & 0.498 & 10.978 \\
\hline Private & cash & 2413 & 0.182 & 0.146 & 0.140 & 0.0002 & 0.866 \\
\hline sector & agency & 2413 & 0.048 & 0.040 & 0.037 & 0.004 & 0.257 \\
\hline \multirow[t]{2}{*}{ sample } & $\mathrm{fc}(\mathrm{KZ})$ & 2413 & 0.470 & 0 & 0.500 & 0 & 1 \\
\hline & $\mathrm{fc}(\mathrm{WW})$ & 2413 & 0.613 & 1 & 0.487 & 01 & 1 \\
\hline Central & $\mathrm{mv}$ & 1409 & 1.618 & 1.158 & 1.263 & 0.498 & 10.978 \\
\hline government & cash & 1409 & 0.176 & 0.138 & 0.135 & 0.003 & 0.805 \\
\hline \multirow[t]{3}{*}{ sample } & agency & 1409 & 0.0483 & 0.0421 & 0.0312 & 0.004 & 0.257 \\
\hline & $\mathrm{fc}(\mathrm{KZ})$ & 1409 & 0.509 & 1 & 0.500 & 0 & 1 \\
\hline & $\mathrm{fc}(\mathrm{WW})$ & 1409 & 0.494 & 0 & 0.500 & 0 & 1 \\
\hline Local & $\mathrm{mv}$ & 3635 & 1.428 & 1.054 & 1.132 & 0.498 & 10.978 \\
\hline government & cash & 3635 & 0.151 & 0.127 & 0.104 & 0.0007 & 0.731 \\
\hline \multirow[t]{3}{*}{ sample } & agency & 3635 & 0.041 & 0.048 & 0.0594 & 0.004 & 0.257 \\
\hline & $\mathrm{fc}(\mathrm{KZ})$ & 3635 & 0.519 & 1 & 0.500 & 0 & 1 \\
\hline & $\mathrm{fc}(\mathrm{WW})$ & 3635 & 0.526 & 1 & 0.500 & 0 & 1 \\
\hline \multicolumn{8}{|c|}{ Panel B } \\
\hline Variable & Dif & $\begin{array}{l}\text { rence of the } \\
\text { mean }\end{array}$ & & lue & $\begin{array}{c}\text { Difference of } \\
\text { median }\end{array}$ & & $Z$ value \\
\hline $\mathrm{mv}$ & & 0.426 & & $30^{* * *}$ & 0.271 & & $14.907^{\star * *}$ \\
\hline cash & & 0.023 & & $2^{* * *}$ & 0.015 & & $5.578^{\star * *}$ \\
\hline agency & & -0.001 & & 978 & -0.001 & & $-2.702^{\star * \star}$ \\
\hline $\mathrm{fc}(\mathrm{KZ}$ index $)$ & & -0.046 & & $90^{* * *}$ & -1 & & $-4.883^{\star * \star}$ \\
\hline $\mathrm{fc}(\mathrm{WW}$ index $)$ & & -0.097 & & $97 * * *$ & 0 & & $11.204^{\star * *}$ \\
\hline
\end{tabular}




\begin{tabular}{ccccc}
\hline \multicolumn{5}{c}{ Panel C } \\
\hline Variable & $\begin{array}{c}\text { Difference of the } \\
\text { mean }\end{array}$ & T value & $\begin{array}{c}\text { Difference of } \\
\text { median }\end{array}$ & Z value \\
\hline $\mathrm{mv}$ & 0.190 & $5.017^{* * *}$ & 0.017 & $5.907^{* * *}$ \\
cash & 0.025 & $6.845^{* * *}$ & 0.011 & $3.862^{* * *}$ \\
agency & 0.007 & 0.585 & -0.006 & $-2.701^{* * *}$ \\
$\mathrm{fc}($ KZ index $)$ & -0.032 & $-2.043^{* *}$ & -1 & $-2.042^{* *}$ \\
$\mathrm{fc}(\mathrm{WW}$ index $)$ & -0.010 & -0.646 & 0 & -0.646 \\
\hline
\end{tabular}

Note: ${ }^{* *},{ }^{* *}$, and ${ }^{*}$ indicate significance at the $1 \%, 5 \%$ and $10 \%$ levels, respectively.

Table 5. Estimated value of regression for all samples.

\begin{tabular}{|c|c|c|c|c|}
\hline & (1) & (2) & (3) & (4) \\
\hline & $\mathrm{mv}$ & $\mathrm{mv}$ & $\mathrm{mv}(\mathrm{KZ}$ index $)$ & $\mathrm{mv}$ (WW index) \\
\hline \multirow[t]{2}{*}{ cons } & $1.845^{\star * *}$ & $1.692^{\star * *}$ & $1.518^{\star * *}$ & $1.648^{\star * *}$ \\
\hline & $(7.27)$ & $(6.74)$ & $(5.50)$ & $(6.07)$ \\
\hline \multirow[t]{2}{*}{ cash } & $0.895^{\star * *}$ & -0.086 & $1.957^{\star * *}$ & $1.250^{\star * *}$ \\
\hline & $(5.34)$ & $(-0.40)$ & $(7.64)$ & $(4.48)$ \\
\hline \multirow[t]{2}{*}{ state } & $-0.218^{* * *}$ & $-0.301^{\star * *}$ & -0.041 & $-0.188^{\star * *}$ \\
\hline & $(-5.50)$ & $(-6.01)$ & $(-0.49)$ & $(-2.79)$ \\
\hline \multirow[t]{2}{*}{ agency } & & $4.599^{* * *}$ & & \\
\hline & & $(7.62)$ & & \\
\hline \multirow[t]{2}{*}{ state $^{*}$ cash } & $-0.402^{\star *}$ & $0.877^{\star * *}$ & $-0.889^{* * *}$ & -0.234 \\
\hline & $(-2.04)$ & $(3.05)$ & $(-2.87)$ & $(-0.74)$ \\
\hline \multirow[t]{2}{*}{ agency ${ }^{*}$ cash } & & $13.066^{\star * *}$ & & \\
\hline & & $(5.86)$ & & \\
\hline \multirow[t]{2}{*}{ state*agency } & & 0.365 & & \\
\hline & & $(0.58)$ & & \\
\hline \multirow[t]{2}{*}{ state $^{*}$ agency $^{*}$ cash } & & $-18.138^{\star * *}$ & & \\
\hline & & $(-4.79)$ & & \\
\hline \multirow[t]{2}{*}{$\mathrm{fc}$} & & & $0.474^{\star * *}$ & $0.395^{\star * *}$ \\
\hline & & & $(5.23)$ & $(5.44)$ \\
\hline \multirow[t]{2}{*}{$\mathrm{fc}^{*} \mathrm{cash}$} & & & $-1.188^{\star}$ & $-0.570^{*}$ \\
\hline & & & $(-1.76)$ & $(-1.66)$ \\
\hline \multirow[t]{2}{*}{ state $^{\star} \mathrm{fc}$} & & & $-0.277^{\star \star}$ & -0.008 \\
\hline & & & $(-2.52)$ & $(-0.09)$ \\
\hline \multirow[t]{2}{*}{ state ${ }^{\star} \mathrm{fc}^{\star}$ cash } & & & 1.042 & -0.288 \\
\hline & & & $(1.26)$ & $(-0.68)$ \\
\hline Controlled variables & Yes & Yes & Yes & Yes \\
\hline $\mathrm{N}$ & 6515 & 6512 & 6515 & 6515 \\
\hline $\mathrm{R}^{2}$ & 0.5617 & 0.5787 & 0.5479 & 0.5519 \\
\hline Adj- $R^{2}$ & 0.5588 & 0.5756 & 0.5446 & 0.5486 \\
\hline $\mathrm{F}$ & 192.837 & 188.90 & 166.724 & 169.448 \\
\hline
\end{tabular}

Note: T-statistics values are in parentheses, ${ }^{* * *},{ }^{* *}$, and $\mathrm{d}^{*}$ indicate significance at the $1 \%, 5 \%$ and $10 \%$ levels, respectively. 
Table 6. Estimated value of regression for SOEs samples.

\begin{tabular}{|c|c|c|c|c|}
\hline & (1) & (2) & (3) & (4) \\
\hline & $\mathrm{mv}$ & $\mathrm{mv}$ & $\begin{array}{c}\mathrm{mv} \\
(\mathrm{KZ} \text { index })\end{array}$ & $\begin{array}{c}\mathrm{mv} \\
(\mathrm{WW} \text { index })\end{array}$ \\
\hline \multirow[t]{2}{*}{ cons } & $3.084^{* * *}$ & $3.143^{* * *}$ & $2.851^{* * *}$ & $2.666^{* * *}$ \\
\hline & (22.56) & $(26.32)$ & (18.64) & (17.48) \\
\hline \multirow[t]{2}{*}{ cash } & 0.208 & 0.149 & $0.859^{* * *}$ & $1.076^{* * *}$ \\
\hline & $(1.34)$ & $(1.05)$ & $(4.22)$ & $(4.93)$ \\
\hline \multirow[t]{2}{*}{ central } & 0.033 & $0.108^{* * *}$ & $0.127^{\star * \star}$ & 0.101 \\
\hline & $(0.75)$ & $(4.44)$ & $(2.90)$ & $(1.52)$ \\
\hline \multirow[t]{2}{*}{ agency } & & $3.791^{* * *}$ & & \\
\hline & & $(9.05)$ & & \\
\hline \multirow[t]{2}{*}{ central $^{*}$ cash } & $0.502^{\star *}$ & $0.541^{* * *}$ & -0.171 & -0.167 \\
\hline & $(2.30)$ & (2.72) & $(-0.56)$ & $(-0.50)$ \\
\hline \multirow[t]{2}{*}{ agency $^{\star}$ cash } & & $-12.768^{\star * *}$ & & \\
\hline & & $(-3.35)$ & & \\
\hline \multirow[t]{2}{*}{ central ${ }^{\star}$ agency } & & $1.343^{*}$ & & \\
\hline & & $(1.86)$ & & \\
\hline \multirow[t]{2}{*}{ cental ${ }^{\star} \operatorname{agency}^{\star}$ cash } & & $11.106^{\star}$ & & \\
\hline & & (1.79) & & \\
\hline \multirow[t]{2}{*}{ fc } & & & $0.334^{* * *}$ & $0.536^{* * *}$ \\
\hline & & & (5.35) & (9.53) \\
\hline \multirow[t]{2}{*}{$\mathrm{fc}^{\star} \mathrm{cash}$} & & & $-1.259^{\star * *}$ & $-1.570^{\star * *}$ \\
\hline & & & $(-3.24)$ & $(-5.22)$ \\
\hline \multirow[t]{2}{*}{ central ${ }^{\star} \mathrm{fc}$} & & & $-0.292^{\star \star \star}$ & -0.077 \\
\hline & & & $(-2.74)$ & $(-0.82)$ \\
\hline \multirow[t]{2}{*}{ central ${ }^{\star} \mathrm{fc}^{\star}$ cash } & & & $2.305^{* \star *}$ & $1.050^{* *}$ \\
\hline & & & $(3.42)$ & $(2.24)$ \\
\hline Controlled variables & Yes & Yes & Yes & Yes \\
\hline $\mathrm{N}$ & 5044 & 5044 & 5044 & 5044 \\
\hline $\mathrm{R}^{2}$ & 0.5885 & 0.6189 & 0.5670 & 0.5768 \\
\hline $\operatorname{Adj}-R^{2}$ & 0.5846 & 0.6150 & 0.5625 & 0.5725 \\
\hline $\mathrm{F}$ & 151.448 & 156.899 & 126.484 & 131.690 \\
\hline
\end{tabular}

Note: T-statistics values are in parentheses, ${ }^{* *},{ }^{* *}$, and ${ }^{*}$ indicate significance at the $1 \%, 5 \%$ and $10 \%$ levels, respectively.

effect of agency conflict on cash holdings could be restricted to some degree in central government-controlled firms. A perplexing finding is that the regression coefficient of agency is positively correlated with firm value. A possible reason for this is that pay and 
executive compensation in SOEs are restricted by governments. As a substitute, executive perquisites (perks) serve as incentives to motivate and reward top managers [36]. This means managing cost (agency cost as calculated in this paper) could play a positive role in firm performance to some extent. In column (3), the financial constraint variable is calculated using the $\mathrm{KZ}$ indexes, the regression coefficient of $\mathrm{fc}^{\star}$ cash is -1.259 , and the coefficient of central ${ }^{*} \mathrm{fc}^{*} \mathrm{cash}$ is 2.305 . Both are significant at the $5 \%$ level. In column (4), $\mathrm{fc}$ is calculated using the WW index, the regression coefficient of $\mathrm{fc}^{*} \mathrm{cash}$ is -1.570 , which is significant at the $1 \%$ level, and the coefficient of central ${ }^{\star} \mathrm{fc}^{\star} \mathrm{cash}$ is 1.050 , which is significant at the $5 \%$ level. While the variable $\mathrm{fc}^{*}$ cash is negatively correlated with $\mathrm{mv}$, the coefficient of central ${ }^{\star} \mathrm{fc}^{\star}$ cash is positively correlated with the explained variable. This observation suggests that value of cash holdings is lower for firms facing a financial constraint, but the correlation between financial constraint and value of cash holdings is weaker in companies controlled by the central government. The result supports hypothesis 3 . Table 6 shows that the value of cash holdings for central government-controlled SOEs is higher than that for local government-controlled SOEs. This result could be attributed to the idea that central government-controlled SOEs are better governed and have better growth prospects compared with local governmentcontrolled SOEs.

\section{Robust Test}

\subsection{Value of Cash Holdings Change}

Model 1 and model 2 mainly discuss the value for total cash holdings. Changes in cash holdings deserve attention. An appropriate question is, "Does the change in value of cash holdings of firms differ with various types of ultimate controllers?" This paper uses the study by Faulkender and Wang as a reference in testing whether the difference rested on the change in cash holdings [21]. The model is the following:

$$
\begin{aligned}
\mathrm{r}_{\mathrm{i}, \mathrm{t}}-\mathrm{R}_{\mathrm{I}, \mathrm{t}}= & \mathrm{r}_{0}+\mathrm{r}_{1} \operatorname{dcash}_{\mathrm{i}, \mathrm{t}} / \mathrm{mv}_{\mathrm{i}, \mathrm{t}-1}+\mathrm{r}_{2} \operatorname{type}_{\mathrm{i}, \mathrm{t}}+\mathrm{r}_{3} \operatorname{type}_{\mathrm{i}, \mathrm{t}} * \operatorname{dcash}_{\mathrm{i}, \mathrm{t}} / \mathrm{mv}_{\mathrm{i}, \mathrm{t}-1} \\
& +\mathrm{r}_{4} \operatorname{dearn}_{\mathrm{i}, \mathrm{t}} / \mathrm{mv}_{\mathrm{i}, \mathrm{t}-1}+\mathrm{r}_{5} \operatorname{dna}_{\mathrm{i}, \mathrm{t}} / \mathrm{mv}_{\mathrm{i}, \mathrm{t}-1}+\mathrm{r}_{6} \operatorname{dcapex}_{\mathrm{i}, \mathrm{t}} / \mathrm{mv}_{\mathrm{i}, \mathrm{t}-1} \\
& +\mathrm{r}_{7} \operatorname{dinter}_{\mathrm{i}, \mathrm{t}} / \mathrm{mv}_{\mathrm{i}, \mathrm{t}-1}+\mathrm{r}_{8} \operatorname{ddivid}_{\mathrm{i}, \mathrm{t}} / \mathrm{mv}_{\mathrm{i}, \mathrm{t}-1}+\mathrm{r}_{9} \operatorname{cash}_{\mathrm{i}, \mathrm{t}-1} / \mathrm{mv}_{\mathrm{i}, \mathrm{t}-1} \\
& +\mathrm{r}_{10} \operatorname{lever}_{\mathrm{i}, \mathrm{t}}+\mathrm{r}_{11} \mathrm{NF}_{\mathrm{i}, \mathrm{t}} / \mathrm{mv}_{\mathrm{i}, \mathrm{t}-1}+\mathrm{r}_{12} \operatorname{cash}_{\mathrm{i}, \mathrm{t}-1} / \mathrm{mv}_{\mathrm{i}, \mathrm{t}-1} * \operatorname{dcash}_{\mathrm{i}, \mathrm{t}} / \mathrm{mv}_{\mathrm{i}, \mathrm{t}-1} \\
& +\mathrm{r}_{13} \text { lever }_{\mathrm{i}, \mathrm{t}} * \operatorname{dcash}_{\mathrm{i}, \mathrm{t}} / \mathrm{mv}_{\mathrm{i}, \mathrm{t}-1}+\sum \mathrm{r}_{14} \mathrm{ind}+\sum \mathrm{r}_{34} \text { year }+\varepsilon_{\mathrm{i}, \mathrm{t}}
\end{aligned}
$$

The dependent variable in the regression model is the excess stock return, $r_{i, t}-R_{I, t}$, where $r_{i, t}$ is the stock return for firm $i$ during fiscal year $t$ and $R_{I, t}$ is stock i's benchmark return at year $t$. This paper uses the stock return of the industry that firm's main business belongs to as benchmark. The variable of dcash $\mathrm{i}_{\mathrm{i}, \mathrm{t}}$ indicates changes in cash holdings from year $\mathrm{t}-1$ to year $\mathrm{t}$. Dearn $\mathrm{i}_{\mathrm{i}, \mathrm{t}} \mathrm{dna}_{\mathrm{i}, \mathrm{t}}$ dcapex $_{\mathrm{i}, \mathrm{t}}$ dinter $_{\mathrm{i}, \mathrm{t}}$ and ddivid $\mathrm{d}_{\mathrm{i}, \mathrm{t}}$ refer to the change in earnings, net assets, capital expenditure, interest expenditure, and cash dividend from year $t$ and year $t-1$. Cash $\mathrm{i}_{\mathrm{i}, \mathrm{t}-1}$ is the cash holdings for firm $\mathrm{i}$ at the end of year $t-1 . \mathrm{NF}_{\mathrm{i}, \mathrm{t}}$ is the net financing during the fiscal year $\mathrm{t}$. Lever $\mathrm{r}_{\mathrm{i}, \mathrm{t}}$ indicates the leverage of firm $i$ at the end of year $t . \mathrm{MV}_{\mathrm{i}, \mathrm{t}-1}$ means the market value of equity at the end of year $t-1$. If the research conclusion is robust, the regression efficient $r_{3}$ should 
be significantly positive.

Table 7 is the regression result for the change in value of cash holdings. In column

Table 7. Robust test result (change of cash holding).

\begin{tabular}{|c|c|c|}
\hline & (1) & (2) \\
\hline & $\mathrm{R}_{\mathrm{i}, \mathrm{t}}-\mathrm{R}_{\mathrm{It}}$ & $\mathrm{R}_{\mathrm{i}, \mathrm{t}}-\mathrm{R}_{\mathrm{It}}$ \\
\hline \multirow[t]{2}{*}{ cons } & 0.048 & 0.034 \\
\hline & $(0.57)$ & $(0.29)$ \\
\hline \multirow[t]{2}{*}{ dcash } & $0.517^{* * *}$ & $0.295^{\star * \star}$ \\
\hline & $(5.87)$ & $(2.64)$ \\
\hline \multirow[t]{2}{*}{ state } & $-0.041^{\star * *}$ & \\
\hline & $(-2.73)$ & \\
\hline \multirow[t]{2}{*}{ state $^{\star}$ dcash } & -0.021 & \\
\hline & $(-0.38)$ & \\
\hline \multirow[t]{2}{*}{ central } & & 0.027 \\
\hline & & (1.08) \\
\hline \multirow[t]{2}{*}{ central $^{\star}$ dcash } & & $0.225^{\star * *}$ \\
\hline & & (2.99) \\
\hline \multirow[t]{2}{*}{ dearn } & $0.380^{* * *}$ & $0.347^{\star \star *}$ \\
\hline & $(9.73)$ & $(6.03)$ \\
\hline \multirow[t]{2}{*}{ dna } & $0.140^{* * *}$ & $0.084^{\star * \star}$ \\
\hline & $(9.31)$ & $(5.65)$ \\
\hline \multirow[t]{2}{*}{ dcapex } & $-0.044^{\star}$ & -0.050 \\
\hline & $(-1.77)$ & $(-1.60)$ \\
\hline \multirow[t]{2}{*}{ dinter } & $-1.724^{\star * *}$ & $-1.443^{* * *}$ \\
\hline & $(-5.81)$ & $(-3.74)$ \\
\hline \multirow[t]{2}{*}{ ddivid } & $0.643^{* * *}$ & $0.950^{\star * *}$ \\
\hline & $(3.77)$ & $(4.02)$ \\
\hline \multirow[t]{2}{*}{ lever } & $0.001^{* * *}$ & $0.162^{\star *}$ \\
\hline & $(2.69)$ & $(2.55)$ \\
\hline \multirow[t]{2}{*}{ NF } & -0.008 & -0.008 \\
\hline & $(-0.85)$ & $(-1.36)$ \\
\hline \multirow[t]{2}{*}{$\mathrm{dcash}^{\star} \operatorname{cash}_{\mathrm{i}, \mathrm{t}-1}$} & $-0.113^{\star * *}$ & $-0.062^{\star *}$ \\
\hline & $(-5.96)$ & $(-2.50)$ \\
\hline \multirow[t]{2}{*}{ lever ${ }^{\star}$ dcash } & $-0.202^{\star}$ & -0.136 \\
\hline & $(-1.73)$ & $(-0.77)$ \\
\hline ind & yes & yes \\
\hline year & yes & yes \\
\hline $\mathrm{N}$ & 6515 & 5044 \\
\hline $\mathrm{R}^{2}$ & 0.0836 & 0.1071 \\
\hline $\operatorname{Adj}-R^{2}$ & 0.0800 & 0.0985 \\
\hline $\mathrm{F}$ & 23.77 & 12.456 \\
\hline
\end{tabular}

Note: T-statistics values are in parentheses, ${ }^{* *},{ }^{* *}$, and ${ }^{*}$ indicate significance at the $1 \%, 5 \%$ and $10 \%$ levels, respectively. 
(1), The regression estimation of state ${ }^{\star}$ dcash is -0.021 , which means that for all samples the change in value of cash holdings for SOEs is lower than that for private firms, but the correlation is not statistically significant. The regression estimation of central $^{\star}$ dcash is 0.225 and significant at the $1 \%$ level. This result suggests that as far as the change in value of cash holdings is concerned, central-government control could bring positive effects.

\subsection{Value of Excess Cash Holdings}

According to firm-level characters, company should have an optimum level of cash holdings (Opler et al., 1999). The difference of real cash holdings and optimum level of cash holdings is excess cash holdings. The study calculates the optimum cash holdings using the determinants of cash holdings model [37 $]^{1}$. The model can predict the optimal cash holdings for every firm in each year. Because the industry variance is an important factor to determine cash holdings, the study uses the industry median value to adjust the predicted value, employs the real cash holdings minus the industry median adjusted predicted value, and obtains the excess cash holdings. This paper uses the term "xcash" to refer to excess cash.

Table 8 shows that coefficient of state ${ }^{\star} \mathrm{xcash}$ is -1.251 , which is significant at the $5 \%$ level. This result means that as far as value of excess cash holdings is concerned, the value for SOEs is lower than that for private firms. The estimator of central ${ }^{*} \mathrm{xcash}$ is 2.640 , which is significant at the $1 \%$ level. This result indicates that value of excess cash holdings could improve more in central-government controlled SOEs than in local government-controlled SOEs. As previously discussed, agency cost should be less serious in central government-controlled SOEs than in local government-controlled SOEs. Moreover, central government-controlled firms rely less on banking than local government-controlled firms do, thereby highlighting the importance of internal cash. The combination of the two factors improves the value of financial flexibility of central government-controlled SOEs compared with local government-controlled SOEs, especially in terms of excess cash holdings, which are more prone to being expropriated by insiders in case of lack of efficient monitoring.

\section{Conclusions}

Previously conducted studies find that the values of cash holdings of firms controlled ${ }^{1}$ The model is as following:

$$
\begin{aligned}
\text { cash }_{\mathrm{i}, \mathrm{t}} / \text { asset }_{\mathrm{i}, \mathrm{t}}= & \alpha_{0}+\alpha_{1} \ln \left(\text { asset }_{\mathrm{i}, \mathrm{t}}\right)+\mathrm{a}_{2} \mathrm{fcf}_{\mathrm{i}, \mathrm{t}} / \text { asset }_{\mathrm{i}, \mathrm{t}}+\alpha_{3} \mathrm{nwc}_{\mathrm{i}, \mathrm{t}} / \text { asset }_{1, \mathrm{t}} \\
& +\mathrm{a}_{4} \text { growth }_{\mathrm{i}, \mathrm{t}}+\alpha_{5} \operatorname{capex}_{\mathrm{i}, \mathrm{t}} / \text { asset }_{\mathrm{i}, \mathrm{t}}+\alpha_{6} \text { lever }_{\mathrm{i}, \mathrm{t}}+\alpha_{7} \operatorname{divid}_{\mathrm{i}, \mathrm{t}} \\
& +\mathrm{a}_{8} \text { inddum }+\mathrm{a}_{9} \text { yeardum }+\varepsilon
\end{aligned}
$$

In the model, cash means cash holdings, which includes cash and cash equivalent, asset is the total assets, fcf means net cash flow, which equals net profit plus depreciation and amortization, nwc is net working capital, which equals working capital minus the cash holdings, growth is the growth rate of the prime operational revenue, capex is capital expenditure, it equals cash paid to acquire fixed assets, intangible assets and other long-term assets minus cash received from disposal fixed assets, intangible assets and other long-term assets, lever is financial leverage, divid is a dummy variable, if firms payout cash dividend in year $t$, it equals 1 , otherwise is 0 , inddum and yeardum are industries and years dummy variables. 
Table 8. Robust test result (excess cash holding).

\begin{tabular}{|c|c|c|}
\hline & $\mathrm{mv}$ & $\mathrm{mv}$ \\
\hline \multirow[t]{2}{*}{ cons } & $1.852^{\star \star *}$ & $2.711^{\star * *}$ \\
\hline & $(7.29)$ & (18.77) \\
\hline \multirow[t]{2}{*}{ xcash } & $2.714^{\star * *}$ & -0.755 \\
\hline & $(5.09)$ & $(-1.53)$ \\
\hline \multirow[t]{2}{*}{ state } & $-0.243^{* * *}$ & \\
\hline & $(-8.23)$ & \\
\hline \multirow[t]{2}{*}{ state $^{\star} x$ cash } & $-1.251^{\star *}$ & \\
\hline & $(-2.21)$ & \\
\hline \multirow[t]{2}{*}{ central } & & 0.031 \\
\hline & & $(0.86)$ \\
\hline \multirow[t]{2}{*}{ central ${ }^{\star}$ xcash } & & $2.640^{\star * *}$ \\
\hline & & $(3.85)$ \\
\hline controlled variables & Yes & Yes \\
\hline $\mathrm{N}$ & 6508 & 5044 \\
\hline $\mathrm{R}^{2}$ & 0.5613 & 0.5621 \\
\hline Adj- $R^{2}$ & 0.5584 & 0.5580 \\
\hline $\mathrm{F}$ & 192.322 & 135.680 \\
\hline
\end{tabular}

Note: T-statistics values are in parentheses, ${ }^{* * *},{ }^{* *}$, and ${ }^{*}$ indicate significance at the $1 \%, 5 \%$ and $10 \%$ levels, respectively.

by different ultimate controllers in China are unequal, but they do not provide a clear explanation for the observation. This paper takes account of government influence, and finds that compared with that of private firms, the value of cash holdings of SOEs is lower. The main reason for this observation is that SOEs have more serious agency problems. The difference has no significant relation with financial constraint. Furthermore, this present study distinguishes among SOEs, classifying SOEs according to levels of government controllers. This study finds that value of cash holdings for central government-controlled SOEs is higher than that for local government-controlled SOEs. The main reason for this observation is that central government-controlled SOEs are relatively better governed and have better growth prospects compared with local government-controlled SOEs. This study contributes to the existing literature on value of cash holdings by considering the emerging market institutional background in China. Findings of this study encourage managers to implement prudent and flexible financial policies and investors to evaluate liquid assets of firms.

This paper considers the agency problem between shareholders and managers. However, concentrated ownership and the agency conflict between block-shareholders and minority shareholders are prevalent in East Asia. The said conflict may influence behavior of shareholders and affect the value of cash holdings. Under different ultimate 
controllers, how this conflict affect value of cash holdings deserves research focus in the future. In addition, market-oriented reform is always in the process in China. During this process, overall government quality improves, but regional differences make this improvement not synchronized among different regions. Moreover, government quality varies across countries. In this context, market-oriented process affects the governance and financial background, and influences value of cash holdings. The mechanism is also worth exploring.

\section{References}

[1] Brealey, R.A., Myers, S.C. and Allen, F. (2007) Principle of Corporate Finance. Machine Industrial Publishing House, Peking, 966-967.

[2] Myers, S. and Rajan, R. (1998) The Paradox of Liquidity. The Quarterly Journal of Economics, 113, 733-771. http://dx.doi.org/10.1162/003355398555739

[3] Jensen, M. (1986) Agency Costs of Free Cash Flow, Corporate Finance and Takeovers. American Economic Review, 76, 323-329.

[4] La-Porta, R., Lopez-de-Silanes, F., Shleifer, A. and Vishny, R. (1999) The Quality of Government. Journal of Law, Economics and Organization, 15, 222-279. http://dx.doi.org/10.1093/jleo/15.1.222

[5] Huang, P. and Zhang, Y. (2009) Corporate Transparency and Cash Holdings: Evidence from Firm-Level Data. Working Paper, National Sun Yat-Sen University, China Taiwan.

[6] Pinkowitz, L. and Williamson, R. (2007) What Is the Market Value of a Dollar of Corporate Cash? Journal of Applied Corporate Finance, 19, 74-81. http://dx.doi.org/10.1111/j.1745-6622.2007.00148.x

[7] Shen, Y., Kuang, X. and Nie, Y. (2008) The Impact of Excess Control of Ultimate Controlling Shareholders on the Value of Cash Holdings. Nankai Business Review, 34, 15-19. (In Chinese)

[8] Gu, N. and Sun, J. (2008) The Market Value of Cash: Evidence of Chinese Listed Companies. Management Science, 21, 96-104. (In Chinese).

[9] Yang, X. and Zhang, Z. (2008) Institution Background, Ownership Property and the Value of Corporate Cash Holdings. Economic Research Journal, 111-123. (In Chinese)

[10] Bardhan, P. (2002) Decentralization of Governance and Development. Journal of Economic Perspectives, 16, 185-205. http://dx.doi.org/10.1257/089533002320951037

[11] Fan, J.P.H., Wei, K.C.J. and Xu, X. (2011) Corporate Finance and Governance in Emerging Markets: A Selective Review and an Agenda for Future Research. Journal of Corporate Finance, 17, 207-214. http://dx.doi.org/10.1016/j.jcorpfin.2010.12.001

[12] Chen, X. and Zhu, H. (2007) Corporate Governance in Transition Economy-Case Study Based on China Listed Companies. Tsinghua University Press, Peking, 10-20. (In Chinese)

[13] Dittmar, A. and Mahrt-Smith, J. (2007) Corporate Governance and the Value of Cash Holdings. Journal of Financial Economics, 83, 599-634. http://dx.doi.org/10.1016/j.jfineco.2005.12.006

[14] Tong, Z. (2011) Firm Diversification and the Value of Corporate Cash Holdings. Journal of Corporate Finance, 17, 741-758. http://dx.doi.org/10.1016/j.jcorpfin.2009.05.001

[15] Yuan, C., Liu, S. and Chen, Y. (2010) Control of Large Shareholder, Diversification, and the Value of Cash Holding. China Industrial Economics, 30, 141-150. (In Chinese)

[16] Kusnadi, Y. (2011) Do Corporate Governance Mechanisms Matter for Cash Holdings and 
Firm Value? Pacific-Basin Finance Journal, 19, 554-570.

http://dx.doi.org/10.1016/j.pacfin.2011.04.002

[17] Fresard, L. and Salva, C. (2010) The Value of Excess Cash and Corporate Governance: Evidence from US Cross-Listings. Journal of Financial Economics, 98, 359-384.

http://dx.doi.org/10.1016/j.jfineco.2010.04.004

[18] Pinkowitz, L., Stulz, R. and Williamson, R. (2006) Does the Contribution of Corpotate Cash Holdings and Dividends to Firm Value Depend on Governance? A Cross-Country Analysis. Journal of Finance, 61, 2725-2751. http://dx.doi.org/10.1111/j.1540-6261.2006.01003.x

[19] Luo, Q. and Qin, G. (2009) The Investor Protection and Corporate Cash Holdings. Journal of Finance Research, 162-178. (In Chinese)

[20] Li, S. (2010) Listing Type of Private Companies: The Deviation of Rights and the Value of Cash Holdings. Economic Management, 101-109. (In Chinese).

[21] Faulkender, M. and Wang, R. (2006) Corporate Financial Policy and the Value of Cash. Journal of Finance, 61, 1957-1990. http://dx.doi.org/10.1111/j.1540-6261.2006.00894.x

[22] Denis, D.J. and Sibilkov, V. (2010) Financial Constraints, Investment, and the Value of Cash Holdings. The Review of Finance Studies, 23, 247-269.

http://dx.doi.org/10.1093/rfs/hhp031

[23] Allen, F., Qian, J. and Qian, M. (2005) Law, Finance, and Economic Growth in China. Journal of Financial Economics, 77, 57-116. http://dx.doi.org/10.1016/j.jfineco.2004.06.010

[24] Zou, H., Wong, S., Shum, C., Xiong, J. and Yan, J. (2008) Controlling-Minority Shareholder Incentive Conflicts and Directors' and Officers' Liability Insurance: Evidence from China. Journal of Banking and Finance, 32, 2636-2645. http://dx.doi.org/10.1016/j.jbankfin.2008.05.015

[25] Chen, G., Firth, M. and Xu, L. (2009) Does the Type of Ownership Control Matter? Evidence from China's Listed Companies. Journal of Banking and Finance, 33, 171-181. http://dx.doi.org/10.1016/j.jbankfin.2007.12.023

[26] World Bank (2012) China 2030: Building a Modern, Harmonious, and Creative High-Income Society. The World Bank.

[27] Xu, L., Xin, Y. and Chen, G. (2006) The Character of Controlling Shareholders and the Firm Performance. The Word Economics, 78-89. (In Chinese)

[28] Xin, Q., Lin, B. and Wang, Y. (2007) Government Controlling, Executive Compensation, and Capital Investment. Journal of Economic Research, 110-122. (In Chinese)

[29] Zhou, L. (2007) Governing China's Local Officials: An Analysis of Promotion Tournament Model. Economic Research Journal, 36-50. (In Chinese)

[30] Wang, Y. and Lin, B. (2008) Financial Intermediary, Informal Financing and Value of Cash Holdings. Journal of Financial Research, 177-199. (In Chinese)

[31] Fama, E.F. and French, K.R. (1998) Taxes, Financing Decisions, and Firm Value. Journal of Finance, 53, 819-843. http://dx.doi.org/10.1111/0022-1082.00036

[32] Kaplan, S. and Zingales, L. (1997) Do Investment-Cash Flow Sensitivities Provide Useful Measures of Financing Constraints? Quarterly Journal of Economics, 112, 169-215.

[33] Whited, T.M. and Wu, G. (2006) Financial Constraint Risk. The Review of Finance Studies, 19, 531-559. http://dx.doi.org/10.1093/rfs/hhj012

[34] Liang, Q., Tian, C. and Zhan, X. (2012) Macroeconomic Uncertainty, Financial Constraints and Firm Cash Holdings in China. South China Journal of Economics, 3-16. (In Chinese)

[35] Fisman, R. (2001) Estimating the Value of Political Connections. American Economic Review, 91, 1095-1102. http://dx.doi.org/10.1257/aer.91.4.1095 
[36] Luo, W., Zhang, Y. and Zhu, N. (2011) Bank Ownership and Executive Perquisites: New Evidence from an Emerging Market. Journal of Corporate Finance, 17, 352-370.

http://dx.doi.org/10.1016/j.jcorpfin.2010.09.010

[37] Opler, T., Pinkowitz, L., Stulz, R. and Williamson, R. (1999) The Determinants and Implications of Cash Holdings. Journal of Financial Economics, 52, 3-46.

http://dx.doi.org/10.1016/S0304-405X(99)00003-3

Submit or recommend next manuscript to SCIRP and we will provide best service for you:

Accepting pre-submission inquiries through Email, Facebook, LinkedIn, Twitter, etc.

A wide selection of journals (inclusive of 9 subjects, more than 200 journals)

Providing 24-hour high-quality service

User-friendly online submission system

Fair and swift peer-review system

Efficient typesetting and proofreading procedure

Display of the result of downloads and visits, as well as the number of cited articles

Maximum dissemination of your research work

Submit your manuscript at: http://papersubmission.scirp.org/ 